\title{
SKIRTINGO AMŽIAUS VYRŲ KŪNO MASĖS IR JOS KOMPONENTÜ POKYČIAI TAIKANT ILGALAIKIUS FIZINIUS PRATIMUS
}

\author{
Algė Vitartaitė, Vytautas Poškaitis, Vincas Bieliūnas, Ričardas Liachovičius, Liutauras Plioplys \\ Kauno medicinos universitetas, Kaunas, Lietuva
}

\begin{abstract}
Algė Vitartaitė. Biomedicinos mokslų daktarė. Kauno medicinos universiteto Kineziologijos ir sporto medicinos katedros docentė. Mokslinių tyrimų kryptis - žmogaus funkcinių galimybių diagnostika ir jo būklei adekvačių poveikių tyrimas.
\end{abstract}

\section{SANTRAUKA}

Daugelis sistemingai sportuojančiu asmenu fiziniais pratimais siekia ne tik padidinti darbinguma, sustiprinti ar išsaugoti sveikata, bet ir sumažinti riebalu masę, koreguoti kūno formas. Tyrimo tikslas — nustatyti, kaip ilgalaikiai fiziniai pratimai veikia juvairaus amžiaus vyru kūno mase ir jos komponentu pokyčius. Tirti teoriškai sveiki vyrai $(n=70)$. Pagal amžiu jie buvo suskirstyti i tris grupes: $(I-20-30 \mathrm{~m} ., n=17 ; I I-30-40 \mathrm{~m}$., $n=33 ; \mathrm{III}-40-$ $50 \mathrm{~m} ., n=20$ ). Antropometriniai rodikliai ir riebalinès odos raukšlès buvo išmatuota du kartus: prieš ir po metu fiziniu pratimu taikymo atskiroms raumenu grupèms lavinti. Tyrimo metu apskaičiuota ir analizuota: kūno masès indeksas (KMI), aktyvioji kūno masè (AKM), santykinè raumenu ir riebalu masé. Rezultatai parodè, kad aktyvioji kūno masé padidèjo $(p<0,05)$ jaunesnio ir vidutinio amžiaus vyru grupèse. Nors santykinè raumenu masè didèjo sulig amžiumi, tačiau nei pirmo, nei antro tyrimo metu statistiškai patikimo reikšmiu skirtumo tarp grupiu nebuvo $(p>0,05)$. Po metu kryptingo fizinio krūvio taikymo santykinè raumenu masè reikšmingai $(p<0,05)$ padidèjo visose vyru amžiaus grupèse. Vertinant santykinès riebalu masès dydžius buvo pastebima šio rodiklio mažèjimo tendencija tarp visu tiriamuju, tačiau tik 30-40 m. amžiaus grupeje šis skirtumas buvo statistiškai patikimas (p < 0,05). Visu tiriamuju kūno masès indeksas po ilgalaikiu treniruočiu nepakito.

Raktažodžiai: aktyvioji kūno masè, santykinè raumenu ir riebalu masè, kūno masès indeksas, ilgalaikiai fiziniai pratimai.

\section{IVADAS}

$\mathrm{V}$ ienas svarbiausių veiksnių, skatinančių ivairaus amžiaus žmones mankštintis, būti fiziškai aktyviems, yra noras gražiau atrodyti, t. y. fiziniais pratimais mažinti kūno masę, keisti kūno formas. Nors šia tema atlikta daugybė moksliniu tyrimų, paskelbta ịvairiausių rekomendaciju, „receptu“, tačiau jos aktualumas išlieka ir šiandien. Kūno masè ir jos komponentai yra tiesiogiai susiję su asmens darbingumu, fiziniu pajègumu. Pastarieji mažiau priklauso nuo žmogaus genetinès programos, todèl kryptingai veikiant galima juos keisti, tobulinti.

Viena didžiausių civilizuotos visuomenès problemų - žmonių, turinčiu antsvori, daugèjimas. V. Grabausko ir kt. autorių (2001) duome- nimis, Lietuvoje $46 \%$ vyru ir $36 \%$ moteru turi antsvori (KMI - 25-29,9 kg/m²), o 19\% vyru ir $35 \%$ moteru yra nutukę (KMI e" $30 \mathrm{~kg} / \mathrm{m}^{2}$ ). Bègant metams, nutukusių žmonių skaičius didejja. Per didelis kūno riebalų kiekis dažniau yra padidejusios hiperlipidemijos, aukšto kraujo spaudimo, išeminès širdies ligos ir diabeto priežastis. Mažinant riebalinio audinio kiekị organizme, dažniausiai rekomenduotini mažo ar vidutinio intensyvumo aerobinį darbingumą didinantys pratimai, kuriu metu greiteja riebalų mobilizacija ir oksidacija. Tačiau ir lokalieji raumenu jègą ugdantys pratimai yra svarbūs riebalinio audinio kiekio mažinimo procese. Nustatyta, kad jẻgos pratimai, didindami aktyviają kūno masę, didina ir 
ramybès metabolini greiti (Lemmer et al., 2001).

Daugelio skirtingo amžiaus vyrų, lankančiu ivairius sveikatingumo, sporto klubus, treniruočiu tikslas - padidinti raumenų masę. Moksliniais tyrimais įrodyta, kad raumenų hipertrofiją daugiausia veikia didelio intensyvumo jègą ugdantys lokalieji pratimai (Abe et al., 2003; McCall et al., 1996; Ploutz et al., 1994). Tačiau neretai neatitinkančios organizmo funkciniu galimybių, vienpusiškos treniruočių programos, kuriose daugiausia dèmesio skiriama didelio intensyvumo lokaliesiems pratimams, sukelia sveikatos problemų: padideja arterinis kraujo spaudimas, atsiranda sąnarių, stuburo perkrovos. Todèl kyla klausimas, ar saugūs pagal tinkamas biomechanines judesiu charakteristikas parinkti mažo ir vidutinio intensyvumo raumenų jègą ugdantys pratimai, taikomi norint didinti ne tik griaučiu ir raumenų sistemos pajègumą, bet gerinti širdies ir kraujagyslių sistemos funkcijas, reguliacinius mechanizmus, ir ar jie gali paveikti kūno masès komponentus? Buvo iškelta hipotezè, kad įvairaus amžiaus vyrų kūno masès komponentai, taikant fizinius pratimus vienerius metus, pakis.

Tyrimo tikslas - nustatyti, kaip ilgalaikiai fiziniai pratimai veikia ívairaus amžiaus vyru kūno masę ir jos komponentu pokyčius.

\section{TIRIAMASIS KONTINGENTAS IR TYRIMO METODAI}

Tyrimai atlikti Kauno sportininkų testavimo ir reabilitacijos centre. Tiriamasis kontingentas teoriškai sveiki vyrai, pagal amžių suskirstyti i tris grupes: $\mathrm{I}-20-30$ metu $(\mathrm{n}=17$; amžiaus vidurkis $-26,2 \pm 0,7$ metu); II $-30-40$ metu $(\mathrm{n}=33$; amžiaus vidurkis $-34,5 \pm 0,55 \mathrm{~m}$. ); III -40 $50 \mathrm{~m}$. ( $\mathrm{n}=20$; amžiaus vidurkis $-44,0 \pm 0,61 \mathrm{~m}$.). Pirmą kartą vyrai buvo tirti tik pradeję lankyti sveikatos stiprinimo grupes. Antras tyrimas atliktas praèjus vieneriems metams po pirmo.

Kūno masès komponentams nustatyti taikytas antropometrijos metodas (Мартиросов, 1982). Ūgis buvo matuojamas metaliniu Martino antropometru, kūno masè - medicininėmis svarstyklèmis. Juosmens, dubens, šlaunies, blauzdos, itempto, atpalaiduoto žasto, dilbio apimtis buvo matuojama centimetrine juostele. Riebalinès odos raukšlès (mentikaulio, krūtinès, pilvo, užpakalinio bei priekinio žasto paviršiaus, dilbio, plaštakos, šlaunies ir blauzdos) išmatuotos Harpeden kaliperiu dešinejje kūno puseje. Buvo apskaičiuojamas kūno masès indeksas (KMI), aktyvioji kūno masè (AKM), santykinė raumenų ir riebalų masė.

Tyrimo duomenims analizuoti buvo taikomi matematinès statistikos metodai: apskaičiuojamas aritmetinis vidurkis $(\bar{x})$, standartinis nuokrypis $(\sigma)$, aritmetinio vidurkio paklaida $(S)$, priklausomų ir nepriklausomų imčių vidurkio skirtumų reikšmingumas pagal Stjudento $t$ kriterijų. Skirtumas (su galima paklaida), mažesnis už 0,05 , buvo vertinamas kaip statistiškai patikimas.

Poveikio apibūdinimas. Dozuotas fizinis krūvis buvo atliekamas pratimų, skirtu atskiroms raumenu grupès lavinti, metu. Sudarant treniruočiu programas, fiziniai pratimai pagal apkrovos pobūdi buvo skirstomi i atliekamus: su izokinetiniais treniruokliais, su svarmenimis ir savo kūno svoriu. Atsižvelgiant ị pratimų struktūros sudètingumą, treniruotès vyksme pamažu buvo pereinama nuo atvirų prie uždarų kinematiniu grandininių judesių. Atliekant visų rūšių lokaliuosius pratimus, ypatingas demesys buvo skiriamas stuburo, liemens funkciniam stabilumui ugdyti. Sudarant treniruočiu programas buvo siekiama, kad fiziniai pratimai subalansuotai veiktų griaučiu raumenų sistemą: nugarinę, priekinę ir šonines kūno sritis, rankas ir kojas; buvo derinami koncentrinis, ekscentrinis raumenų darbo režimai. Parenkant apkrovos dydi, atsižvelgta į atskirų raumenu grupiu pradinio, saugaus testavimo pagal 10 RM metodiką rezultatus. Krūvio intensyvumas svyravo nuo 40 iki $70 \%$ maksimaliosios raumenu jègos, nustatytos testavimo metu. Vienos treniruotès trukmè -1 valanda, dažnumas -2 arba 3 kartai per savaitę. Treniruočių programa buvo sudaroma atsižvelgiant $\mathfrak{i}$ funkcinio pajègumo vertinimo, anketavimo rezultatus ir asmens pageidavimus.

\section{REZULTATAI}

Kaip matyti iš lentelès, skirtingo amžiaus vyrų KMI pokyčiai, taikant ilgalaikius raumenų funkcini pajëgumą didinančius pratimus, buvo statistiškai nereikšmingi $(p>0,05) .20-30 \mathrm{~m}$. grupeje KMI turèjo tendenciją didèti, vyresnių vyrų grupèse - mažèti. Palyginus šio rodiklio reikšmes tarp grupiu nustatyta, kad abiejų tyrimų metu jauniausiu (20-30 m.) vyru grupejje KMI buvo daug $(\mathrm{p}<0,05)$ mažesnis negu vyriausių $(40-$ $50 \mathrm{~m}$.).

1 paveiksle pavaizduoti tiriamujų AKM pokyčiai. Pirmo tyrimo metu, t. y. prieš pradedant lan- 


\begin{tabular}{|c|c|c|c|c|c|c|c|}
\hline \multirow[t]{19}{*}{$\begin{array}{l}\text { Lentelè. Vyrų kūno masės kom- } \\
\text { ponentų rodikliai prieš ir po } \\
\text { fizinių pratimų taikymo }\end{array}$} & $\begin{array}{l}\text { Tiriamujų } \\
\text { grupé }\end{array}$ & Tyrimas & Rodikliai & $\mathrm{KMI}, \mathrm{kg} / \mathrm{m}^{2}$ & $\mathrm{AKM}, \mathrm{kg}$ & $\begin{array}{l}\text { Raumenų } \\
\text { masė, \% }\end{array}$ & $\begin{array}{l}\text { Riebalų } \\
\text { masė, \% }\end{array}$ \\
\hline & \multirow{6}{*}{$20-30$} & \multirow{3}{*}{ I } & $\bar{x}$ & 23,78 & 62,86 & 45,48 & 19,96 \\
\hline & & & $\sigma$ & 2,80 & 6,08 & 3,42 & 6,24 \\
\hline & & & $S \bar{x}$ & 0,68 & 1,47 & 0,83 & 1,51 \\
\hline & & \multirow{3}{*}{ II } & $\bar{x}$ & 23,86 & 64,06 & 47,05 & 18,86 \\
\hline & & & $\sigma$ & 2,51 & 7,20 & 3,20 & 6,94 \\
\hline & & & $S \bar{x}$ & 0,61 & 1,75 & 0,77 & 1,68 \\
\hline & \multirow{6}{*}{$30-40$} & \multirow{3}{*}{ I } & $\bar{x}$ & 25,93 & 65,70 & 44,43 & 23,20 \\
\hline & & & $\sigma$ & 3,02 & 6,40 & 2,81 & 5,80 \\
\hline & & & $S \bar{x}$ & 0,53 & 1,11 & 0,49 & 1,01 \\
\hline & & \multirow{3}{*}{ II } & $\bar{x}$ & 25,86 & 67,47 & 47,01 & 20,88 \\
\hline & & & $\sigma$ & 2,88 & 6,20 & 3,14 & 5,35 \\
\hline & & & $S \bar{x}$ & 0,50 & 1,08 & 0,55 & 0,93 \\
\hline & \multirow{6}{*}{$40-50$} & \multirow{3}{*}{ I } & $\bar{x}$ & 27,95 & 69,67 & 44,19 & 24,07 \\
\hline & & & $\sigma$ & 2,32 & 10,83 & 3,92 & 6,6 \\
\hline & & & $S \bar{x}$ & 0,52 & 2,42 & 0,88 & 1,48 \\
\hline & & \multirow{3}{*}{ II } & $\bar{x}$ & 27,76 & 70,54 & 45,43 & 22,21 \\
\hline & & & $\sigma$ & 2,44 & 9,07 & 2,73 & 4,17 \\
\hline & & & $S \bar{x}$ & 0,55 & 2,03 & 0,61 & 0,93 \\
\hline
\end{tabular}

kyti sveikatą stiprinančias pratybas, AKM 20$30 \mathrm{~m}$. vyru grupeje buvo $62,86 \pm 1,47 \mathrm{~kg}, 30-$ $40 \mathrm{~m}$. grupèje $-65,70 \pm 1,11 \mathrm{~kg}$ ir vyriausiu grupejje $-69,67 \pm 2,42 \mathrm{~kg}$. Atliktų tyrimų duomenimis, AKM labiausiai padidèjo $(1,77 \pm 0,48 \mathrm{~kg}$, $\mathrm{p}<0,05) 30-40 \mathrm{~m}$. vyru grupeje. Statistiškai patikimą AKM padidejjimą užregistravome ir jauniausių vyru grupeje, kur jis siekè 1,19 $\pm 0,55 \mathrm{~kg}$ $(\mathrm{p}<0,05)$. Vyriausių tiriamujų $(40-50 \mathrm{~m}$.) grupèje AKM antro tyrimo metu buvo $70,54 \pm 2,03 \mathrm{~kg}$. Užregistruotas pokytis $(1,24 \pm 0,76 \mathrm{~kg})$ buvo statistiškai nepatikimas $(\mathrm{p}>0,05)$.

Didžiausia santykinè raumenų masė prieš pradedant taikyti raumenu pajègumą didinančius pratimus buvo $20-30 \mathrm{~m}$. vyrų grupèje $45,48 \pm 0,83 \%$ (2 pav.). Nedaug mažesni dydžiai buvo užregistruoti kitose grupèse: $44,43 \pm 0,49 \%$ (30-40 m.) ir 44,19 $\pm 0,88 \%$ (40-50 m.). Po metu atlikus antropometrinius matavimus nustatyta, kad santykinè raumenų mase ịvairaus amžiaus vyrų grupèse padidejo statistiškai patikimai $(p<0,05)$. Didžiausias šio rodiklio reikšmių skirtumas nustatytas $30-40 \mathrm{~m}$. tiriamuju grupejje $-2,58 \pm 0,41 \%$. Vidutinio amžiaus vyru raumenu masé antro tyrimo metu sudarè $47,01 \pm 0,55 \%$ nuo kūno masès. Beveik toks pat santykinès raumenų masės dydis užregistruotas $20-30 \mathrm{~m}$. tiriamuju grupejje $-47,05 \pm 0,86 \%$. $40-50 \mathrm{~m}$. vyru grupeje santykinè raumenų masè po ilgalaikių fizinių pratimų buvo kiek mažesnè nei pirmose grupèse ir sudare $45,43 \pm 0,61 \%$ nuo kūno masès. Nei pirmo, nei antro tyrimo metu statistiškai patikimo raumenų masės reikšmių skirtumo tarp grupių nebuvo pastebėta $(\mathrm{p}>0,05)$.

Pirmo tyrimo duomenimis, $20-30 \mathrm{~m}$. am-

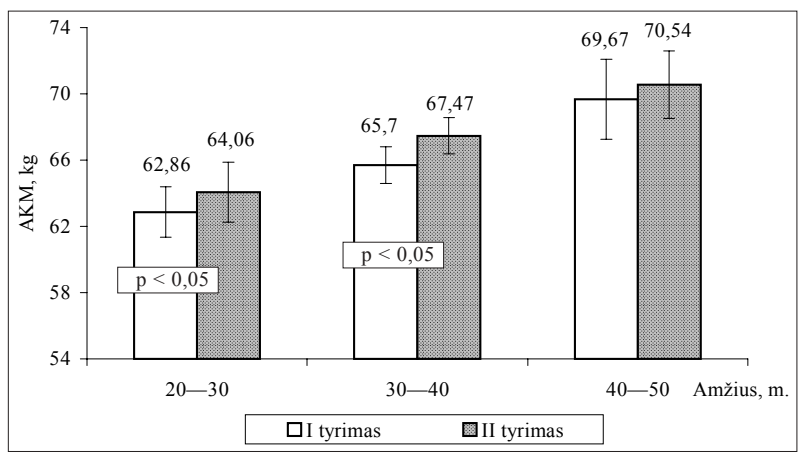

1 pav. İvairaus amžiaus vyrų aktyviosios kūno masės pokytis 


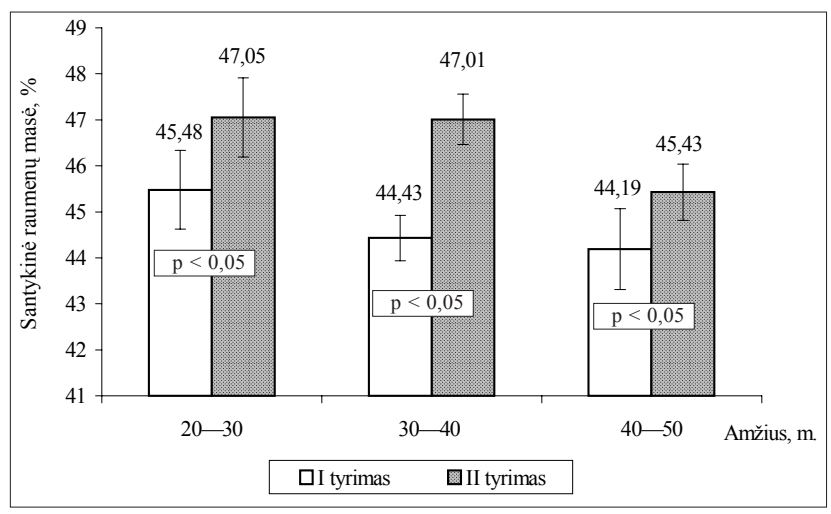

2 pav. Santykinės raumenų masės pokytis skirtingo amžiaus vyrų grupèse

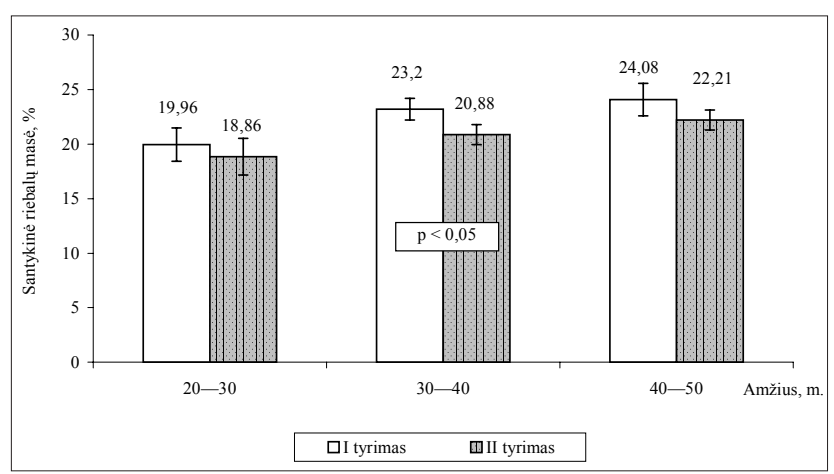

3 pav. Santykinès riebalų masės pokytis taikant lokaliuosius fizinius pratimus

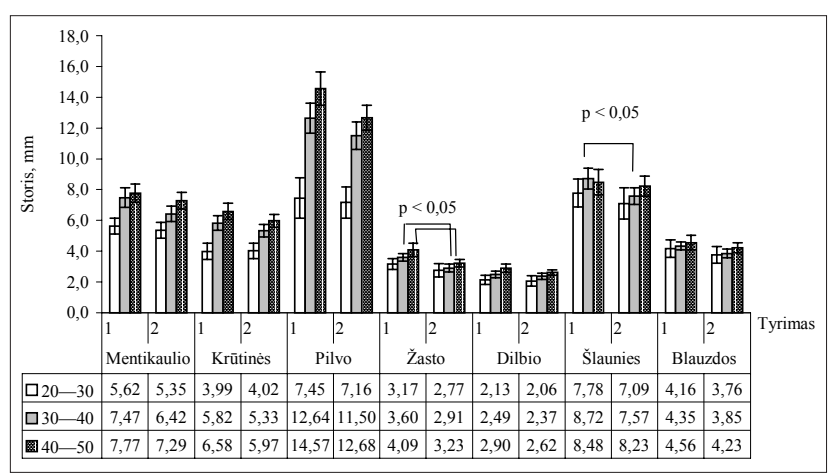

4 pav. Riebalinių odos raukšlių duomenys prieš ir po ilgalaikių fizinių krūvių

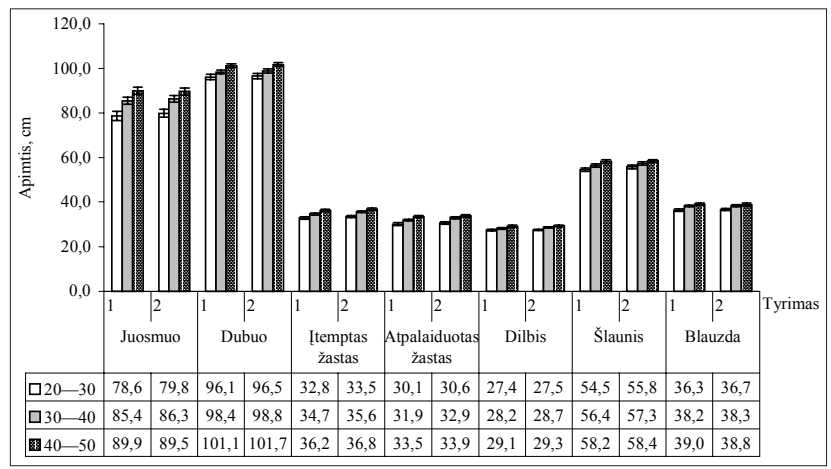

5 pav. Kūno dalių apimtis prieš ir po ilgalaikių fizinių krūvių žiaus vyrai turèjo mažiausią ( $\mathrm{p}<0,05)$ santykinę riebalų masę ( 3 pav.). Didejjant amžiui, riebalinio audinio kiekis turejo tendenciją didèti. Po metų trukmès fizinių pratimų visose amžiaus grupèse buvo užregistruotas santykinès riebalų masès sumažèjimas. Jeigu $30-40 \mathrm{~m}$. amžiaus grupejje nustatytas ryškus $(\mathrm{p}<0,05)$ riebalų masès sumažejimas $(2,32 \pm 0,67 \%$ nuo kūno masès $)$, tai jauniausių ir vyriausių vyrų grupèse šio rodiklio pokytis buvo nedidelis $(\mathrm{p}>0,05)$ - sudare atitinkamai $1,11 \pm 1,02$ ir $1,87 \pm 1,04 \%$.

Analizuojant riebalinių odos raukšlių (ROR) reikšmes tarp skirtingo amžiaus tiriamuju grupių nustatyta, kad 20-30 m. vyrų mentikaulio, krūtinès ir pilvo ROR abiejų tyrimų metu buvo reikšmingai mažesnès $(p<0,05)$ nei vyresniu vyru grupèse (4 pav.). Tuo tarpu ranku ir kojų ROR dydžiai tarp skirtingo amžiaus tiriamujų buvo panašūs. Tyrimo rezultatai parodè, kad 30-40 m. vyrų grupeje žasto ir šlaunies, o $40-50 \mathrm{~m}$. žasto, ROR reikšmės antro tyrimo metu buvo daug $(\mathrm{p}<0,05)$ mažesnès nei pirmo. Jauniausių vyru grupejje pastebèta visų ROR mažèjimo tendencija.

Atlikus atskirų kūno dalių apimties matavimą nustatyta, kad didèjant amžiui didèja ir kūno dalių apimtis ( 5 pav.). Palyginus abiejų tyrimų rezultatus pastebètos matuotų kūno dalių apimties didejimo tendencijos visose vyrų grupėse $(p>0,05)$.

\section{REZULTATŲ APTARIMAS}

Vienas labiausiai paplitusių kūno masės vertinimo rodikliu yra KMI. Teigiama, kad yra atvirkštinè priklausomybè tarp fizinio aktyvumo ir KMI (Hardman, 1998). Atlikti tyrimai parodè, kad po metų trukmès raumenų pajègumą didinančių pratimų ìvairaus amžiaus vyrų kūno mase beveik nepakito. Ivertinus tiriamujų kūno masę pagal KMI standartines normas (Lohman, 1995) matyti, kad tik 20-30 m. vyrų kūno masè buvo optimali, tuo tarpu vidutinio ir vyresnio amžiaus vyrai turejo per didelę kūno masę (jų KMI viršijo normos ribas - 19,0-24,9 $\mathrm{kg} / \mathrm{m}^{2}$ ). Toks vertinimas išliko ir antro tyrimo metu. Pastovi kūno masè neturètu būti siejama su atskiru jos komponentų stabilumu, todèl vertinant fizinių pratimų poveikį kūno kompozicijai yra svarbu nustatyti aktyviosios, riebalinès masès santykị su kūno mase.

AKM geriausiai nusako energijos išeikvojimą žmogaus organizme (Westerterp et al., 1992). Moksliniais tyrimais įrodyta, kad AKM turi itakos ivairaus amžiaus asmenų maksimaliajam aerobi- 
niam pajègumui (Hunt et al., 1998). Taigi AKM didejjimas yra svarbus stiprinant sveikatą ne tik dèl raumenų pajègumo, bet gali prisidèti prie širdies ir kraujagyslių sistemos funkcijų bei metabolizmo gerinimo. Žmogaus aktyviają kūno masę daugiausia lemia fizinis aktyvumas ir amžius. Fiziškai neaktyvių asmenų AKM sumažèjimas apie 15\% pastebimas tarp trečio ir aštunto gyvenimo dešimtmečio (Evans, 1995). Nors kiti autoriai (Hunt et al., 1998) tvirtina, kad maža AKM lemia ne amžius, bet nepakankamas fizinis aktyvumas. Mūsų rezultatai patvirtina ankstesnių studijų išvadas, teigiančias, kad taikant dozuotą fizini krūvị galima išlaikyti ir padidinti ivairaus amžiaus žmoniu AKM (Hughes et al., 2002).

Nepriklausomai nuo lyties santykinè raumenų masè mažèja nuo trečio gyvenimo dešimtmečio, o absoliuti - nesikeičia net iki penkto (Jansse et al., 2000). Kitų autorių duomenimis, raumenų masès mažejimas prasideda nuo ketvirto gyvenimo dešimtmečio (Fiatarone Singh, 2002), tačiau sarkopenija ryškiausiai pastebima sulaukus 5060 m. (Evans, 1995; Rosenber, 1997). Sarkopenija daugiausia lemia kontraktilinių medžiagų kiekis, baltymų sintezès greičio mažejimas, greitai susitraukiančiu raumenų skaidulų atrofija (Tipton, Wolfe, 1998). Duomenis apie raumenų masès mažèjimą didejjant amžiui patvirtina ir mūsų tyrimo rezultatai.

Atlikta daug tyrimų, įrodančių, kad raumenų jègą didinantys pratimai gali sukelti raumenu hipertrofiją (Grund et al., 2001; McCall et al., 1996). Lavinant raumenų jègą, padideja miofibrilių, sarkomerų kiekis (Tipton, Wolfe, 2001). Nustatyta, kad atliekant fizinius pratimus, skirtus atskiroms raumenų grupems lavinti, labiau hipertrofuojasi greito susitraukimo raumenų skaidulos (Ploutz et al., 1994). Raumens adaptaciją prie fizinių krūvių lemia raumens susitraukimo tipas, raumenų darbo režimai ir kt. K. E. Yarasheski (2002) teigimu, jègą ugdanti treniruote yra efektyvi nefarmakologine terapija, kuri gerina raumenų baltymų kokybę bei didina jų kieki ypač tada, kai žmogus yra vidutinio ir vyresnio amžiaus. Mūsų tyrimų duomenimis, raumenų masès padidèjimas $(\mathrm{p}<0,05)$ buvo pastebètas visų tiriamuju grupèse.

Riebalinio audinio atsargoms mažinti taikomi i̇vairūs metodai. Mažinant kūno riebalų masę, sveikiausias ir efektyviausias yra fiziniu pratimu ir dietos derinys, nes tai padeda išsaugoti aktyviają kūno masę ir raumenų jègą. Fizinio krūvio efektyvumas mažinant riebalinio audinio kieki priklauso nuo jo dydžio ir nuo energijos sąnaudu.

Gauti rezultatai parode, kad pirmo tyrimo metu tik jauniausio amžiaus vyrų riebalų mase atitiko standartines normas, tuo tarpu vyresniu grupèse nustatytas riebalinio audinio kiekio perteklius (Lohman, 1995). Šiuos rezultatus patvirtino ir KMI. Po metu fiziniu pratimu taikymo sumažéjusi riebalų mase jau buvo vertinama kaip normali, nors KMI vyresnių vyru grupèse išliko per didelis. Šie rezultatai patvirtina nuomonę, kad taikant KMI metodiką reikia atsižvelgti ir i tiriamujų raumenų masę (Lohman, 1995).

Raumenu ir riebalų masès pokyčius rodo atskirų kūno dalių apimties ir riebalinių odos raukšlių matavimas. Riebalinių odos raukšlių mažèjimo tendencija patvirtino nuomonę, kad atliekant raumenu jègą lavinančius pratimus riebalai kaip energinė medžiaga naudojama selektyviai (CallesEscandon, Poehlman, 1997).

\section{IŠVADOS}

1. Dèl ilgalaikių reguliarių fizinių pratimų visose amžiaus grupése santykinè vyrų raumenų masė padidèjo $(\mathrm{p}<0,05)$.

2. Jaunesnio ir vidutinio amžiaus vyrų grupèse buvo nustatytas aktyviosios kūno masès padidejjimas $(\mathrm{p}<0,05)$, o vyriausių grupèje pastebetos šio rodiklio kitimo tendencijos.

3. Po metų sveikatos stiprinimo pratybų santykinè riebalų masè sumažèjo $(\mathrm{p}<0,05) 30-40 \mathrm{~m}$. amžiaus vyru grupèje, visų tiriamujų kūno masès indeksas išliko nepakitęs.

\section{LITERATŪRA}

Abe, T., Kojima, K., Kearns, C. F. et al. (2003). Whole body muscle hypertrophy from resistance training: Distribution and total mass. British Journal of Sports Medicine, 37 (6), 543-545.

Calles-Escandon, J., Poehlman, E. T. (1997). Aging fat oxidation and exercise. Aging, 9, 57-63.

Evans, W. J. (1995). What is sarcopenia? Journal of Gerontology, 50, 5-10.
Fiatarone Singh, M. A. (2002). Benefits of exercise and dietary measures to optimize shifts in body composition with age. Asia Pacific Journal of Clinical Nutrition, 11, S 642-652.

Grabauskas, V., Klumbienė, J., Petkevičienė, J. ir kt. (2001). Suaugusiu Lietuvos žmoniu gyvensenos tyrimas, 2000. Helsinkis: Publications the National Public Health Institute. 
Grund, A., Krause, H., Kraus, M. et al. (2001). Association between different attributes of physical activity and fat mass in untrained, endurance-and resistance-trained men. European Journal of Applied Physiology, 84, 310-320.

Hardman, A. E. (1998). Exercise for health. Ugdymas. Kūno kultūra. Sportas, 1 (29), 25-38.

Hughes, V. A., Fronetra, W. R., Roubenoff, R., Evans, W. J., Singh, M. A. (2002). Longitudinal changes in body composition in older men and women: Role of body weight change and physical activity. American Journal of Clinical Nutrition, 76, 473-481.

Janseen, I., Heymsfield, S. B., Wang, Z., Ross, R. (2000). Skeletal muscle mass and distribution in 468 men and women aged 18-88 yr. Journal of Applied Physiology, $89,81-88$.

Lemmer, J. T, Ivey, F. M., Ryan, A. S. et al. (2001). Effect of strength training on reting metabolic rate and physical activity: Age and gender comparisons. Medicine and Science in Sports and Exercise, 33, 532-541.

Lohman, T. (1995). Practical Body Composition. Human Kinetics.

McCall, G. E., Byrnes, W. C., Dickinson, A. et al. (1996). Muscle fiber hypertrophy, hyperplasia, and capillary density in college men after resistance training. Journal of Applied Physiology, 81, 2004-2012.

Ploutz, L. L., Tesch, P. A., Biro, R. L. et al. (1994). Effects of resistance training on muscle use during exercise. Journal of Applied Physiology, 76, 1675-1681.

Tipton, K. D., Wolfe, R. R. (2001). Exercise, protein, metabolism, and muscle growth. International Journal of Sport Nutrition \& Exercise Metabolism, 11, 109-132.

Tipton, K. D., Wolfe, R. R. (1998). Exercise-induced changes in protein metabolism. Acta Physiologica Scandinavica, 162, 377-387.

Westerterp, K. R., Meijer, G. A., Kester, A. D., Wouters, L., ten Hoor, F. (1992). Fat-free mass as a function of fat mass and habitual activity level. International Journal of Sports Medicine, 13, 163-166.

Yarasheski, K. E. (2003). Review article: Exercise, aging, and muscle protein metabolism. Journal of Gerontology Series A: Biological Sciences and Medical Sciences, 58, 918-922.

Yarasheski, K. E. (2002). Managing sarcopenia with progressive resistance exercise training. Journal of Nutrition Health Aging, 6, 349-356.

Мартиросов, Э. Г. (1982). Методы исследования в спортивной антропологии. Москва. С. 38-52.

\title{
THE CHANGES IN BODY COMPOSITION OF DIFFERENT AGE MALES UNDER THE INFLUENCE OF LONG-TERM PHYSICAL EXERCISES
}

\author{
Algė Vitartaitė, Vytautas Poškaitis, Vincas Bieliūnas, Ričardas Liachovičius, Liutauras Plioplys \\ Kaunas University of Medicine, Kaunas, Lithuania
}

\begin{abstract}
One of the most important components of physical capacity and health is not only muscle strength but also body composition and fat free mass. A lot of persons, who are improving their health by systematic physical exercises, are seeking not only for the increase of physical capacity and health maintenance, but also for the loss of fat mass.

The aim of the study was to assess the influence of long-term physical exercises on a male's body composition. The males, without clinical symptoms $(\mathrm{n}=70)$, were tested and divided into three age groups: (I $-20-30$ years old, $\mathrm{n}=17$; II $-30-40$ years old, $\mathrm{n}=33$; III $-40-50$ yeas old, $\mathrm{n}=20$ ). Anthropometric measurements were done twice: before, and one year after physical exercises. In the work: body mass index, fat free mass, relative muscle and fat mass were investigated. Our research results showed that, fat free mass increased $(\mathrm{p}<0.05)$ in two age groups: young and middle age. Differences in relative muscle mass among three groups were statistically insignificant $(p>0.05)$ in both measurements. After long-term physical training, the increase of relative muscle mass was statistically significant $(p<0.05)$ in all age groups. The decrease of relative fat mass was observed in all age groups, but only in 30-40 years old group the difference was statistically significant $(\mathrm{p}<0.05)$.
\end{abstract}

Keywords: fat free mass, relative muscle and fat mass, body mass index, physical exercises.

Gauta $2004 \mathrm{~m}$. balandžio $7 \mathrm{~d}$.

Received on April 7, 2004

Priimta $2005 \mathrm{~m}$. vasario $2 \mathrm{~d}$.

Accepted on February 2, 2005
Algè Vitartaitè

Kauno medicinos universitetas

(Kaunas University of Medicine)

M. Jankaus g. 2, LT-50275 Kaunas

Tel +37037730580

Lietuva (Lithuania)

E-mail algevitartaite@hotmail.com 